This is an electronic reprint of the original article. This reprint may differ from the original in pagination and typographic detail.

Author(s): Kotiaho, Janne Sakari; Mönkkönen, Mikko

Title: $\quad$ From a crisis discipline towards prognostic conservation practise : an argument for setting aside degraded habitats

Year: $\quad 2017$

Version:

Please cite the original version:

Kotiaho, J. S., \& Mönkkönen, M. (2017). From a crisis discipline towards prognostic conservation practise : an argument for setting aside degraded habitats. Annales Zoologici Fennici, 54(1-4), 27-37. https://doi.org/10.5735/086.054.0105

All material supplied via JYX is protected by copyright and other intellectual property rights, and duplication or sale of all or part of any of the repository collections is not permitted, except that material may be duplicated by you for your research use or educational purposes in electronic or print form. You must obtain permission for any other use. Electronic or print copies may not be offered, whether for sale or otherwise to anyone who is not an authorised user. 


\title{
From a crisis discipline towards prognostic conservation practise: an argument for setting aside degraded habitats
}

\author{
Janne S. Kotiaho* \& Mikko Mönkkönen
}

\begin{abstract}
University of Jyväskylä, Department of Biological and Environmental Science, P.O. Box 35, Fl-40014 University of Jyväskylä, Finland ( ${ }^{*}$ corresponding author's e-mail: janne.kotiaho@jyu.fi)
\end{abstract}

Received 7 Nov. 2016, final version received 13 Feb. 2017, accepted 13 Feb. 2017

Kotiaho, J. S. \& Mönkkönen, M. 2017: From a crisis discipline towards prognostic conservation practise: an argument for setting aside degraded habitats. - Ann. Zool. Fennici 54: 27-37.

In addition we only need time. And that is not in short supply. (Viljo Kujala 1941)

On the opening page of his pioneering work, Soule (1985) highlights that "Although crisis oriented, conservation biology is concerned with the long-term viability of whole systems". To some extent the crisis orientation hints to the pressing timelines of operational conservation while the latter part is more about ecology, population biology and science in general. Soule (1985) was careful with the wording, but nevertheless, ever since conservation biology has been framed one way or another as a crisis discipline (e.g., Meffe 2001, Pullin 2002, Wilson 2002, Meine et al 2006, Sodhi \& Ehrlich 2010). In the science of conservation biology, the crisis discipline statement is often supplemented with some variation of the original idea that the focus has to be in safeguarding the long-term survival of species, populations and functioning of the ecosystems. However, despite the recognition in science, it appears that operational conservation is somewhat disconnected from the science (Pullin et al. 2004, Knight et al. 2008, Arlettaz et al.2010) and is predominantly approaching the conservation problem from the crisis perspective. The fact that operational conservation decision making is often based on ecological values we currently have in any given focal ecosystem (or the lack thereof) and seldom considers space or time, and thus is not based on a mechanistic understanding of the long-term survival of populations, serves as a good example. Here we advance an argument for prognostic conservation practice in which we should recognise the future ecological potential of areas despite of their current degraded ecological values. We consider our suggestion for prognostic conservation practise to be an interesting parallel to the general time management problems discussed by Meffe (2001) in an editorial in Conservation Biology on problems of obtaining good quality timely peer reviews. Citing Covey (1989), Meffe explained that "any activity can be judged as urgent or not urgent and as important or not important. When placed in a two-by-two matrix, four quadrants result: I, urgent and important; II, not urgent and important; III, urgent and not important; and IV, not urgent and not important. Covey argues that effective people avoid activities in quadrants III and IV as much as possible, minimize activities in quadrant I (the crisis management area), and maximize activities in quadrant II, where good and creative work occurs in a calm and reasoned environment." We believe that prognostic conservation practise belongs to the quadrant II and thus shifts the operational conservation away from crisis management area towards the good and creative conservation work. We begin with general arguments for increased 
area and then deepen the argument with a specific example from boreal ecosystems.

\section{More area covers more species!}

The positive relationship between the number of species found in a habitat and its area is one of the most fundamental empirical generalizations in ecological science (Rosenzweig 1995, Lawton 1999, Gaston \& Blackburn 2000, O’Dwyer \& Green 2010, Rybicki \& Hanski 2013, Hanski 2016). Indeed, in conservation biology the relationship between the area of habitat and the number of species often plays a role when we are trying to understand how habitat loss affects the risk of extinction (Tilman et al. 1994, Swift \& Hannon 2010, Rybicki \& Hanski 2013, Hanski 2000, 2016; for other models see Ladle 2009). Theoretical and empirical works on various taxa from plants and fungus to coral, insects, birds and mammals have documented that local extinction of species does follow habitat loss although often with a considerable time lag called the extinction debt (Tilman et al. 1994, Cowlishaw 1999, Hanski 2000, Brook et al. 2003, Munday 2004, Stuart et al. 2004, Thomas et al. 2004, Berglund \& Jonsson 2005, Helm et al. 2006, Ford et al. 2009, Kuussaari et al. 2009, Jackson \& Sax 2010, Sang et al. 2010, Triantis et al. 2010, Selonen \& Kotiaho 2013).

What is interesting, however, is that we appear to be focusing on the inverse of the relationship with respect to conservation. Indeed, research seems to be more occupied with determining how habitat loss will influence the loss of species rather than trying to work out how increasing habitat area would enhance the survival of the remaining ones or improve species coverage of a conservation area network (Mönkkönen et al. 2009). Why should this be? In part, this is likely to reflect the business as usual thinking in which the biologists and perhaps even the authorities responsible for the management and conservation of landscapes acknowledge that habitat loss is the reality and this trend is not really anticipated to be reversing.

In most textbooks of ecology and conservation biology, one can read that species conservation is ultimately connected to the idea of habitat con- servation (e.g., Pullin 2002, Hanski 2005, 2016, Primack 2006). This is something that most of us tend to agree with. Nevertheless, it appears that the reality of rampantly ongoing habitat loss may have caused us to mentally give up this idea and perhaps somewhat unintentionally to shift our focus into apparently more fertile and gratifying areas of conservation research and practice. Indeed, rather than steadfastly trying to set aside and protect more area we seem to have shifted into thinking how to improve the quality of the areas we have already succeeded to set aside. It is easy to see why such a shift may have taken place: Many (if not most) conservation areas and setasides in western society have a history of long and intensive utilisation causing extensive habitat degradation and thus resulting into the deterioration of the conservation value of the conservation areas. To reverse the habitat degradation, it has been globally agreed that extensive restoration of the degraded habitats should be undertaken (e.g., https://www.cbd.int/sp/targets/, http://www. un.org/sustainabledevelopment/sustainable-development-goals/). In the past decade we saw an increase in restoration actions aiming to rehabilitate the structures and functions that were typical of natural ecosystems followed by research aiming to document the anticipated ecological successes and the feared economical risks of the restoration actions (e.g., Toivanen \& Kotiaho 2007a, 2007b, Vanha-Majamaa et al. 2007, Junninen et al. 2008, Komonen \& Kouki 2008, Toivanen et al. 2009, Olsson \& Jonsson 2010, Toivanen \& Kotiaho 2010, Haapalehto et al. 2011, Moreno-Mateos et al. 2012, Groot et al. 2013). We think that restoration indeed is an important tool in our conservation toolbox (see e.g., Kotiaho et al. 2015, 2016a, 2016b), but perhaps not the most important one until we have secured enough area for conservation purposes.

The problem, of course, is that it is virtually impossible to determine how much area is enough for all species to persist in any given area. There just is no single threshold value for all species (Mönkkönen \& Reunanen 1999, Fahrig 2001, Tear et al. 2005, Hanski 2005, 2016), and even if there were, it would simply be too high to be realistically achievable in the current political or socio-economical context. Nevertheless, area needed is certainly more than the few percent- 
ages that are set aside in many western countries. Various global working groups have provided recommendations that each nation should protect ca. $10 \%$ of the total area (reviewed in Svancara et al. 2005) and more recently this target was revised to be $17 \%$ for terrestrial and $10 \%$ for marine world respectively (https://www.cbd.int/ sp/targets/; see also Pouzols et al. 2014). However, what needs to be noted is that the often repeated $10 \%$ rule-of-thumb, or even the current $17 \%$ target, is not a scientifically derived value for the biological conservation needs but rather it is a negotiated policy-driven compromise that is a convenient politically achievable target; as Svancara et al. (2005) eloquently put it: "The 10 percent conservation target or goal is an arbitrary value, but one that has gained considerable popularity in the past two decades, without evidence of biological substance or conservation merit". Indeed, in conservation target setting science and politics often mix to such an extent that it is impossible to tell where the science stops and the political pragmatism takes over (see also Hanski 2002, Tear et al. 2005, Ahlroth \& Kotiaho 2009, Kotiaho et al. 2016a).

Unfortunately, similar, albeit sometimes unrecognised, arbitrary conservation target setting is common in one of the most influential current tools of practical conservation i.e. the systematic conservation planning framework (Margules \& Pressey 2000, Margules \& Sarkar 2007, Moilanen et al. 2009). Systematic conservation planning prioritizes areas for conservation first, by locating areas with the highest a priori ecological values (targets) that best complement the existing conservation area network (Pressey et al. 2007) and second, by minimizing the losses of the ecological values within the areas of the highest and most complementary ecological values (Pressey et al. 2004, Nicholson et al 2006, Visconti et al. 2011). Foundational to the systematic conservation planning framework is the aim of satisfying the conservation targets with minimum cost. Because priority is given to areas with the highest present ecological values, the minimum cost requirement may translate into finding the smallest area possible satisfying the ecological targets and thus, may maximize species extinction in the long run (Cabeza \& Moilanen 2001). It may be worth mentioning that this is a feature rather than a fault in the target setting framework. The problem is that because the above framework is dependent on a priori target setting and aims at cost-effective satisfaction of the targets, it may become easy to overlook the problem that still in the first place we do not know how much area is enough for all species to persist (Tilman et al. 1994, Cabeza \& Moilanen 2003, Svancara et al. 2005, Tear et al. 2005). Therefore, even when we use the stateof-the-art methods for locating the best possible areas for conservation, we may not reach the actual overarching target i.e., maintaining the biodiversity and ecological values in the long run (but see Maron et al. 2012, Moilanen 2012, Kareksela et al. 2013).

Given that we do not know how much area set-aside and protected is enough, but understanding that it is certainly more than what we have at the moment, we suggest that our primary focus in operational conservation efforts should be directed towards securing more area - even if it means that we must start setting aside degraded areas. Arguments for restoration rather than setting aside more area rest on the assumption that the little area we already have set aside will be sufficient to protect the biodiversity, provided we just improve the quality of the conservation areas themselves and the adjacent managed areas. The arguments laid down above suggest that this is not the case - we need more area! We agree that restoration is a valuable tool to increase the quality of the habitats, but what must not be forgotten is that while the quality of the habitat may have an influence on how much area of any given habitat needs to be set-aside and protected, the determining factor still is the area.

We argue that to effectively combat habitat loss, the appreciation of the importance of the area should be revitalized; in this case quality does not substitute for quantity. It easily appears that the ecological values peak at the best remaining patches of the natural habitats, such as old growth forests, and thus these are the areas we should aim to set aside and protect. The problem, of course, is that in reality setting aside the remaining natural habitats incurs opportunity costs prohibitively large for society at large to accept it. This is because rapidly increasing human population size sets increasing demands 
for global conversion of natural habitats into productive land (Meyer \& Turner 1992, Foley et al. 2005, Polasky et al. 2008). Indeed, societies appear to be increasingly adopting the values of venture capitalism and endless desire for more growth, in which apparent cost-efficiency and fast revenues are the only values that count. Due to discounting we tend to prefer actions that yield fast profits compared with actions that accumulate slowly even when the total profits would be greater in the long run. We agree that we must be cost-effective in everything we conserve because wasting limited conservation budget is simply not sensible but the strive for cost-efficiency should not work contrary to sustainability.

This raises the question of how to do costeffective conservation in a sustainable way. Cost-benefit analysis provides a widely accepted method to achieve cost-efficient solutions and the economically optimal level of conservation actions. In this setting, the question is how large economic costs today we are willing to accept in order to achieve environmental benefits in the future. The rate at which we discount the future decisively affects the conservation actions that seem economically warranted today (Mazziotta et al 2016, Ranius et al. 2016). In a cost-benefit analysis the objective is to maximize the benefits-to-costs ratio. If we apply discount rates of $x$ and $y$ for economic costs and environmental benefits, respectively, we can formulate the objective to maximize $[B \times \exp (y)] /[C \times \exp (x)]$, where $B$ refers to environmental benefits and $C$ to economic costs. By rearranging, the equation reduces to $B \times \exp (z) / C$ where $z$ is $(y-x)$.

The private discount rate, such as a market interest rate, is suitable for calculating the economic costs to land owners. However, environmental benefits can be considered a social investment, and therefore, a social discount rate is needed to evaluate impacts of social conservation project or policy. It has been argued that the social discount rate should be lower than the market interest rate because biodiversity assets are non-substitutable and non-reproducible (Azar \& Sterner 1996, Philibert 2003, Guo et al. 2006, Gollier 2010, Kula \& Evans 2011). Consequently, assuming that $y<x$, the final discount rate of environmental benefits, $z$, will be (perhaps only slightly) negative. This effectively means that future benefits from conservation projects should be valued higher than the immediate benefits. On these grounds we argue that a current investment not providing immediate returns but doing so during future generations should be a very valuable investment - even more valuable than an investment that will bring immediate but ephemeral revenues.

\section{The argument}

Above we made general arguments for the priority of setting aside more area, and a rationale for doing it cost-effectively. To deepen our argument we next take a specific example, but note that the arguments we are making are general and that similar examples can be found in other ecosystems and regions. We draw our example from the boreal forest ecosystems and argue that we should purchase clear-cut forests and set them aside for nature conservation purposes.

The problem with forest conservation is that the areas that we traditionally value the most in terms of conservation are simultaneously the most valuable for timber production i.e., the oldgrowth forests, thus creating a conflict between economic and ecological values (Mönkkönen 1999, Pautasso 2007). Therefore, if we want to conserve more area with our limited conservation budgets, the solution is to set aside the areas that are not so much valued from the economic point of view (see e.g., Lundström et al. 2011, Mazziotta et al. 2016, Ranius et al. 2016). Here the distinction we made between the private and social discount rates makes a difference: Once the fast economical revenues from clear-cutting a mature forest have been reaped the economic value of the area is dramatically decreased. As far as the price of the forest land is considered the clear-cut land is as cheap as it gets. Many will argue that the clear-cut will have no ecological values worth setting aside (see below), but it is worth noting that these persons have adopted the doctrine of private discounting rather than the social one: provided the clear-cut is set aside today we may expect large ecological values to be obtained in a hundred or so years, and given a negative discount rate (see above), these large 
future benefits should be valued higher than the immediate low benefits. Therefore, our argument is that purchasing clear-cut forests in conservation-strategically important locations (e.g., close to existing reserves) and setting them aside for nature conservation purpose is a part of a palette of cost-effective conservation actions and that our policy-targets for conservation should be modified accordingly (see also Hanski 2011, Rybicki \& Hanski 2013, Kotiaho 2017).

We are not opposing protection of the remaining old-growth patches, but rather wish to point out that obtaining large areas of clear-cuts in conservation-strategically important locations could cost-effectively assist our mission to carry the current biodiversity across generations. We say across generations because we are convinced that we really need to be taking a longer perspective on the conservation problem. We should shift our focus from resolving immediate conservation crises towards prognostic conservation practise and plan for a long-term survival of populations and species. Unfortunately, the short-termism inherent to our political systems and societal decision making, as well as that in research funding is likely to present significant resistance to prognostic approaches that rely on decadal or even across-generation planning.

To plan across generations, we also need to consider the following question: how can we ensure that the today's political decision to set aside clear-cuts is upheld in the future. Indeed, we need to consider that the areas that may now be economically uninteresting will become economically interesting again. The dilemma is particularly likely to arise because the economic value of the clear-cut is likely to increase faster than its ecological value. While it may indeed be impossible to tie the hands of the future generations, we already have long history of legislation we adhere to and thus one way would be to develop the legislation to better safeguard the set asides in the future. The problem of political unpredictability will presumably be higher with set-asides that currently have high economic values than with current clear-cuts, and thus, our inability to ensure the persistence of set-asides cannot be used as an argument of not establishing them.

Abandoning the crisis orientation in favour of more prognostic conservation practise may also mean that we have to admit that it may not be possible to save all the extant species. The ones that are now threatened may in fact be under severe extinction debt and some of them perhaps cannot be saved no matter what we do. Admitting that we may lose some does not mean that we should give up, but by shifting the focus of conservation actions and research questions from species that are already at the brink of extinction to those that are not quite yet there, just might help us save more of the latter ones in the long run (McIntyre 1992, Bottrill et al.2008, 2009, McDonald-Madden et al. 2008, Wilson et al 2011, DiMarco et al. 2012, Kotiaho \& Halme 2014). What is the worry is that if (or because) we are unable to stop the ongoing habitat loss it is very likely that the species not yet threatened will become so in some not so distant future. Therefore, to combat habitat loss in the long run, we suggest purchasing large areas of clear-cuts in conservation-strategically important locations (e.g., close to existing reserves) and setting them aside for conservation purposes.

\section{Three common arguments against setting aside clear-cuts}

\section{We are in a hurry to save the little old growth we have left so that species do not go extinct and thus we cannot afford to set aside the clear-cuts}

This argument harbours two implicit, somewhat nested, presumptions: (i) that species are going to go extinct very rapidly, and (ii) by conserving the little old growth we have left would prevent those rapid extinctions. The second presumption is likely to be flawed. The biodiversity is already in decline despite the fact that the old growth forest fragments that could be set aside have existed in the landscape all the time. Thus, it is unlikely that saving only these fragments, or in fact anything we have at the moment, is sufficient to stop the loss of species. Indeed, this argument appears to be turning into the favour of restoration: the only way of stopping the current loss of species is to stop habitat loss and start to improve the quality of the protected habitats. Even if we halt the degradation now we will still 
be losing species due to the extinction debt and in order to create species credit (Hanski 2000) we indeed need to restore the degraded habitats.

The first presumption is a bit more challenging. However, what we know of the responses of species to the degradation of habitat or habitat loss is that extinction tends not to be immediate but rather that considerable time lags are involved. This time lag is causing the extinction debt (Tilman et al. 1994, Hanski 2000, Kuussaari et al. 2009, Jackson \& Sax 2010). There are now numerous studies that show that indeed the extinctions are likely to follow but that the time needed may be surprisingly long, in many cases extending more than a century (e.g., Lindborg \& Eriksson 2004, Junninen \& Komonen 2011, Sang et al. 2010). So, it appears that if not all, at least many species may resist extinction for more than a century suggesting that, in fact, we still may have time to start conservation from a conservation-strategically well located clearcuts.

\section{There is nothing worth conserving in the clear-cut}

This argument is somehow reflecting our tendency to think primarily of the benefits here and now and discount the ones that are achievable in long time spans of a century or so. Even if it really was the case that there is little worth conserving now it does not constitute evidence that this will be the case also in the long run (see e.g., Segerstöm et al. 2004, Humphrey 2005, Chazdon et al. 2009). The fact is that the forests in many regions will regenerate, re-establish important habitat characteristics, reach maturity and eventually approach old-growth perhaps already after a century or so. Given the long relaxation time for extinction debt discussed above, it appears likely that we still have species that can colonise these secondary old growth forests.

One can also question the factual claim in this argument: is it really a fact that there is nothing at the clear-cuts worth conserving? Numerous studies and comparisons have been conducted on the species assemblages at the clear-cuts. Although many species or species groups obviously are negatively affected by the clear-cutting (e.g., Niemelä 1997) it is not an uncommon finding that clear-cuts are not void of species, and actually often harbour equally many or even more species than the old-growth forests (e.g., Pykälä 2004, Selonen et al. 2005, Widenfalk \& Weslien 2009, Johansson et al. 2010). However, what is perhaps surprising to some is that there are large amounts of dead wood on clear-cuts (Eräjää et al. 2010), and that several studies actually report findings of species on clear-cuts that are considered to be under risk of extinction (e.g., Martikainen 2001, SverdrupThygeson \& Ims 2002, Junninen et al. 2006, Jonsell 2007, 2008, Jonsell et al. 2007). Thus, clear-cuts do provide some values immediately, and if set-aside, high values in the future.

\section{If we start setting aside clear-cuts we will definitively lose the remaining old growth}

Well, the world just is not so black and white, even though setting aside clear-cuts does not come without a price. We are not suggesting that we should exclusively focus on setting aside clear-cuts. On the contrary, instead of the exclusive focus on the tiny fragments of good quality old growth we suggest that we should also, i.e. in addition to old growth, consider setting aside larger areas of clear-cut. By allocating all our conservation resources into the old-growth we can expect high immediate return but for very restricted quantity, while allocating some of the resources to clear-cuts we may expect low immediate return that is compensated by the large quantity and expected higher return in the long run. If we simultaneously consider both short- and long-term conservation targets we can probably achieve more than by focusing on only one of the two (e.g., Mazziotta et al. 2016, Ranius et al. 2016).

A question then arises, what proportion of limited conservation resources should be allocated for setting aside clear-cuts vs. old growth. The answer critically hinges on time discounting of economic costs and environmental benefits. Mazziotta et al. (2016) concluded that the optimal share of investments on setting aside clear-cuts increases when the difference between private and social discount rate increases. In 
another study, Ranius et al. (2016) compared the relative utility setting aside young forests, setting aside old forest and prolonging rotations. The comparison was focused on a longterm extinction risk of a dead wood-dependent beetle (Diacanthous undulates) metapopulation in a $50 \mathrm{~km}^{2}$ landscape in central Sweden, using a colonization-extinction model. They found that in the long-term (200 years) the extinction risk was lowest when about $80 \%$ of the budget was allocated for setting aside the oldest stands and the remaining $20 \%$ for setting aside the youngest ones. While Ranius et al. (2016) did not evaluate time discounting of conservation benefits, they concluded that the optimal strategy depends on the assumed societal values and hence discount rates.

Even if we do not know the optimal strategy yet, the message from the limited available evidence is clear: a cost-efficient conservation portfolio includes investments on setting aside clear-cuts. If we invested $20 \%$ of the available resources in clear-cuts and $80 \%$ in old growth, and assume that the opportunity cost of setting aside clear-cut is one tenth of the cost of setting aside old growth, we would acquire almost three times larger increment in the area of a conservation network than in the old-growth-only policy; with a 50: 50 share the increment would already be 5.5 times greater.

\section{Conclusions}

If we really want to conserve biodiversity for future generations we may need to abandon the crisis-oriented approach from our conservation actions, move towards prognostic conservation practise and set aside more area. It may be that in order to obtain significant increments in our conservation area networks we must start focusing on areas that are not directly competing with society's economic interests in terms of revenues from the timber or food production. These areas are the clear-cuts and other degraded areas. By augmenting our conservation area networks with large areas of cheap clear-cuts we are not responding to a crisis we have already observed nor are we looking for the fast revenues here and now, but rather we are making a prognostic decision and conserving for future generations - just as we should be.

This is not the first time the idea of setting aside clear-cuts has been advanced. Indeed, as early as in 1941, Viljo Kujala, professor of forest biology and the founding member and a long-term president of the Board of the Finnish Association for Nature Conservation, suggested that the dire lack of nature reserves in the southern half of Finland could have been resolved by setting aside clear-cuts: "Since even in southern Finland the original forest plant species still exist and are ready to re-colonise areas that have become cleared out, it is obvious that here we can establish a nature reserve on an area that is for example completely clear-cut or burnt to barren. In addition we only need time. And that is not in short supply." (translated by the authors from Kujala 1941: 35). Just imagine if the authorities some 75 years ago would have been visionary enough to implement Kujala's suggestion of setting aside large areas of clearcuts in southern Finland in already degraded areas! Unfortunately, they were not.

Through the above discussion and suggestion of setting aside large areas of clear-cut, we aim to draw attention to the need to move from shortsighted crisis orientation towards more prognostic conservation practise. If we do it now and aim at setting aside more area instead of looking for apparently cost-effective minimum area solutions, we can foresee that within a century or so our successors may be in a position of declaring that finally we are getting close to the global biodiversity targets in achieving a significant reduction in or indeed halting the loss of biological diversity.

\section{Acknowledgements}

We thank Santtu Kareksela and Atte Moilanen for the numerous invaluable discussions where a blind eye was never turned to the problems in conservation science and practise. We thank Tapio Lindholm for pointing us to the Viljo Kujala's publication and Jussi Päivinen and Adriano Mazziotta for comments. This manuscript has been peer reviewed in Peerage of Science. We thank an anonymous Peer for making us aware, and thus helping us to avoid biological subculture jargon we were using in a previous version of our manuscript. 


\section{References}

Ahlroth, P. \& Kotiaho, J. S. 2009: Route for political interests to weaken conservation. - Nature 460: 173-173.

Arlettaz, R., Schaub, M., Fournier, J., Reichlin, T. S., Sierro, A., Watson, J. E. M. \& Braunisch, V. 2010: From publications to public actions: when conservation biologists bridge the gap between research and implementation. Bioscience 60: 835-842.

Azar, C. \& Sterner, T. 1996: Discounting and distributional considerations in the context of global warming. - Ecological Economics 19: 169-184.

Berglund, H. \& Jonsson, B. G. 2005: Verifying an extinction debt among lichens and fungi in northern Swedish boreal forests. - Conservation Biology 19: 338-348.

Bottrill, M. C., Joseph, L. N., Carwardine, J., Bode, M., Cook, C., Game, E. T., Grantham, H., Kark, S., Linke, S., McDonald-Madden, E., Pressey, R. L., Walker, S., Wilson, K. A. \& Possingham, H. P. 2008: Is conservation triage just smart decision making? - Trends in Ecology \& Evolution 23: 649-654.

Bottrill, M. C., Joseph, L. N., Carwardine, J., Bode, M., Cook, C., Game, E. T., Grantham, H., Kark, S., Linke, S., McDonald-Madden, E., Pressey, R. L., Walker, S., Wilson, K. A. \& Possingham, H. P. 2009: Finite conservation funds mean triage is unavaoidable? - Trends in Ecology \& Evolution 24: 183-184.

Brook, B. W., Sodhi, N. S. \& Ng, P. K. L. 2003: Catastrophic extinctions follow deforestation in Singapore. - Nature 424: 420-426.

Cabeza, M. \& Moilanen, A. 2001: Design of reserve networks and the persitence of biodiversity. - Trends in Ecology \& Evolution 16: 242-248.

Cabeza, M. \& Moilanen, A. 2003: Site-selection algorithms and habitat loss. - Conservation Biology 17: 14021413.

Chazdon, R. L., Peres, C. A., Dent, D., Sheil, D., Lugo, A. E., Lamb, D., Stork, N. E. \& Miller, S. E. 2009: The potential for species conservation in tropical secondary forests. - Conservation Biology 23: 1406-1417.

Covey, S. R. 1989: The 7 habits of highly successful people. - Free Press, New York, USA.

Cowlishaw, G. 1999: Predicting the pattern of decline of African primate diversity: an extinction debt from historical deforestation. - Conservation Biology 13: 11831193.

Di Marco, M., Cardillo, M., Possingham, H. P., Wilson, K. A., Blomberg, S. P., Boitani, L. \& Rondinini, C. 2012: A novel approach for global mammal extinction risk reduction. - Conservation Letters 5: 134-141.

Eräjää, S., Halme, P., Kotiaho, J. S., Markkanen, A. \& Toivanen, T. 2010: The volume and composition of dead wood on traditional and forest fuel harvested clear-cuts. - Silva Fennica 44: 203-211.

Fahrig, L. 2001: How much habitat is enough? - Biological Conservation 100: 65-74.

Foley, J. A., DeFries, R., Asner, G. P., Barford, C., Bonan, G., Carpemter, S. R., Chapin, F. S., Coe, M. T., Daily, G. C., Gibbs, H. K., Helkowski, J. H., Holloway, T., Howard,
E. A., Kucharik, C. J., Monfreda, C., Patz, J. A., Prentice, I. C., Ramankutty, N. \& Snyder, P. K. 2005: Global consequences of land use. - Science 309: 570-574.

Ford, H. A., Walters, J. R., Cooper, C. B., Debus, S. J. S. \& Doerr, V. A. J. 2009: Extinction debt or habitat change? - Ongoing losses of woodland birds in north-eastern New South Wales, Australia. - Biological Conservation 142: 3182-3190.

Gaston, K. J. \& Blackburn, T. M. 2000: Pattern and process in macroecology. - Blackwell Science, Oxford.

Gollier, C. 2010: Ecological discounting. - Journal of Economic Theory 145: 812-829.

Groot, R. S., Blignaut, J., Ploeg, S., Aronson, J., Elmqvist, T. \& Farley, J. 2013: Benefits of investing in ecosystem restoration. - Conservation Biology 27: 1286-1293.

Guo, J., Hepburn, C. J., Tol, R. S. \& Anthoff, D. 2006: Discounting and the social cost of carbon: a closer look at uncertainty. - Environmental Science \& Policy 9: 205-216.

Haapalehto, T. O., Vasander, H., Jauhiainen, S., Tahvanainen, T. \& Kotiaho, J. S. 2011: The effects of peatland restoration on water-table depth, elemental concentrations, and vegetation: 10 years of changes. - Restoration Ecology 19: 587-598.

Hanski, I. 2000: Extinction debt and species credit in boreal forests: modelling the consequences of different approaches to biodiversity conservation. - Annales Zoologici Fennici 37: 271-280.

Hanski, I. 2002: In the midst of ecology, conservation, and competing interests in the society. - Annales Zoologici Fennici 39: 183-186.

Hanski, I. 2005: The shrinking world: ecological consequences of habitat loss. - International Ecology Institute, Oldendorf/Luhe, Germany.

Hanski, I. 2011: Habitat loss, the dynamics of biodiversity, and a perspective on conservation. - Ambio 40: 248-255.

Hanski, I. 2016: Tutkimusmatkoja saarille: luonnon monimuotoisuutta kartoitamassa. - Gaudeamus, Helsinki.

Helm, A., Hanski, I. \& Pärtel, M. 2006: Slow response of plant species richness to habitat loss and fragmentation. - Ecology Letters 9: 72-77.

Humphrey, J. W. 2005: Benefits to biodiversity from developing old-growth conditions in British upland spruce plantations: a review and recommendations. - Forestry 78: 33-53.

Jackson, S. T. \& Sax, D. F. 2010: Balancing biodiversity in a changing environment: extinction debt, immigration credit and species turnover. - Trends in Ecology \& Evolution 25: 153-160.

Johansson, T., Hjältén, J., Stenbacks, F. \& Dysenius, M. 2010: Responses of eight boreal flat bug (Heteroptera: Aradidae) species to clear-cutting and forest fire. Journal of Insect Conservation 14: 3-9.

Jonsell, M. 2007: Effects on biodiversity of forest fuel extraction, governed by processes working on a large scale. - Biomass and Bioenergy 31: 726-732.

Jonsell, M. 2008: Saproxylic beetle species in logging residues: which are they and which residues do they use? Norwegian Journal of Entomology 55: 109-122. 
Jonsell, M., Hansson, J. \& Wedmo, L. 2007: Diversity of saproxylic beetle species in logging residues in Sweden - comparisons between tree species and diameters. Biological Conservation 138: 89-99.

Junninen, K. \& Komonen, A. 2011: Conservation ecology of boreal polypores: a review. - Biological Conservation 144: 11-20.

Junninen, K., Kouki, J. \& Renvall, P. 2008: Restoration of natural legacies of fire in European boreal forests: an experimental approach to the effects on wood-decaying fungi. - Canadian Journal of Forest Research 38: 202-215.

Junninen, K., Similä, M., Kouki, J. \& Kotiranta, H. 2006: Assemblages of wood-inhabiting fungi along the gradients of succession and naturalness in boreal pine-dominant forests in Fennoscandia. - Ecography 29: 75-83.

Kareksela, S., Moilanen, A., Tuominen, S. \& Kotiaho, J. S. 2013: Use of inverse spatial conservation prioritization to avoid biological diversity loss outside protected areas. - Conservation Biology 27: 1294-1303.

Knight, A. T., Cowling, R. M., Rouget, M., Balmford, A., Lombard, A. T. \& Campbell, B. M. 2008: Knowing but not doing: selecting priority conservation areas and the research-implementation gap. - Conservation Biology 22: 610-617.

Komonen, A. \& Kouki, J. 2008: Do restoration fellings in protected forests increase the risk of bark beetle damages in adjacent forests? A case study from Fennoscandian boreal forest. - Forest Ecology and Management 255: 3736-3743.

Kotiaho, J. S. 2017: On effective biodiversity conservation, sustainability of bioeconomy, and honesty of the Finnish forest policy. - Annales Zoologici Fennici 54: 13-25.

Kotiaho, J. S., ten Brink, B. \& Harris, J. 2016a: A global baseline for ecosystem recovery. - Nature 532: 37.

Kotiaho, J. S. \& Halme, P. 2014: Aggregating protected habitats embraces implicit habitat conservation triage. - ProcPoS 1: e5, doi:10.14726/procpos.2014.e5.

Kotiaho, J. S., Kuusela, S., Nieminen, N. \& Päivinen, J. (eds.) 2015: Elinympäristöjen tilan edistäminen Suomessa. - The Finnish Environment 8, Ympäristöministeriö, Helsinki.

Kotiaho, J. S., Kuusela, S., Nieminen, E., Päivinen, J. \& Moilanen, A. 2016b: Framework for assessing and reversing ecosystem degradation. - Reports of the Ministry of the Environment $15 \mathrm{en}$, Helsinki.

Kujala, V. 1941: Luonnonpuistokysymys Suomen eteläpuoliskossa. - Suomen Luonto 1: 33-36.

Kula, E. \& Evans, D. 2011: Dual discounting in cost-benefit analysis for environmental impacts. - Environmental Impact Assessment Review 31: 180-186

Kuuluvainen, T., Aapala, K., Ahlroth, P., Kuusinen, M., Lindholm, T., Sallantaus, T., Siitonen, J. \& Tukia, H. 2002: Principles of ecological restoration of boreal forested ecosystems: Finland as an example. - Silva Fennica 36: 409-422.

Kuussaari, M., Bommarco, R., Heikkinen, R. K., Helm, A., Krauss, J., Lindborg, R., Öckinger, E., Pärtel, M., Pino, J., Rodà, F., Stefanescu, C., Teder, T., Zobel, M. \& Steffan-Dewenter, I. 2009: Extinction debt: a challenge for biodiversity conservation. - Trends in Ecology \& Evolution 24: 564-571.

Ladle, R. J. 2009: Forecasting extinctions: uncertainties and limitations. - Diversity 1: 133-150.

Lawton, J. H. 1999: Are there general laws in ecology? Oikos 84: 177-192.

Lindborg, R. \& Eriksson, O. 2004: Historical landscape connectivity affects present plant species diversity. - Ecology 85: 1840-1845.

Lundström, J., Öhman, K., Perhans, K., Rönnqvist, M. \& Gustafsson, L. 2011: Cost-effective age structure and geographical distribution of boreal forest reserves. Journal of Applied Ecology 48: 133-142.

Margules, C. R. \& Pressey, R. L. 2000: Systematic conservation planning. - Nature 405: 243-253.

Margules, C. R. \& Sarkar, S. 2007: Systematic conservation planning. - Cambridge University Press, Cambridge.

Maron, M., Hobbs, R. J., Moilanen, A., Matthews, J. W., Christie, K., Gardner, T. A., Keith, D., Lindenmayer, D. B. \& McAlpine, C. A. 2012: Faustian bargains? Restoration realities in the context of biodiversity offset policies. - Biological Conservation 155: 141-148.

Martikainen, P. 2001: Conservation of threatened saproxylic beetles: significance of retained aspen Populus tremula on clearcut areas. - Ecological Bulletins 49: 205-218.

Mazziotta, A., Pouzols, F. M., Mönkkönen, M., Kotiaho, J. S., Strandman, H. \& Moilanen, A. 2016: Optimal conservation resource allocation under variable economic and ecological time discounting rates in boreal forest. Journal of Environmental Management 180: 366-374.

McDonald-Madden, E., Peter, W. J., Baxter, P. W. J. \& Possingham, H. P. 2008: Making robust decisions for conservation with restricted money and knowledge. - Journal of Applied Ecology 45: 1630-1638.

McIntyre, S., Barrett, G. W., Kitching, R. L. \& Recher, H. F. 1992: Species triage-seeing beyond wounded rhinos. Conservation Biology 1992: 604-606.

Meffe, G. K. 2001: Crisis in a crisis discipline. - Conservation Biology 15: 303-304.

Meine, C., Soulé, M. \& Noss, R. F. 2006: A mission-driven discipline: the growth of conservation biology. - Conservation biology 20: 631-651.

Meyer, W. B. \& Turner, B. L. I. 1992: Human population growth and global land-use/cover change. - Annual Review of Ecology and Systematics 23: 39-61.

Moilanen, A., Wilson, K. A. \& Possingham, H. P. (eds.) 2009: Spatial conservation prioritization. - Oxford University Press, Oxford.

Moilanen, A. 2012: Planning impact avoidance and biodiversity offsetting using software for spatial conservation prioritisation. - Wildlife Research 40: 153-162.

Moreno-Mateos, D., Power, M. E., Comín, F. A. \& Yockteng, R. 2012: Structural and functional loss in restored wetland ecosystems. - PLoS Biol. 10(1): e1001247, doi:10.1371/journal.pbio.1001247.

Munday, P. L. 2004: Habitat loss, resource specialization, and extinction on coral reefs. - Global Change Biology 10: $1642-1647$.

Mönkkönen, M. 1999: Managing northern boreal forest landscapes for biodiversity: ecological and economic per- 
spectives. - Biodiversity and Conservation 8: 85-99.

Mönkkönen, M. \& Reunanen, P. 1999: On critical thresholds in landscape connectivity - management perspective. - Oikos 84: 302-305

Mönkkönen, M., Juutinen, A. \& Hurme, E. 2009: Setting targets: trade-offs between ecology and economics. - In: Villard, M.-A., Drapeau, P. \& Jonsson, B. G. (eds.), Setting conservation targets for managed forest landscapes: 328-351. Cambridge University Press, Cambridge, UK.

Nicholson, E., Westphal, M. I., Frank, K., Rochester, W. A., Pressey, R. L., Lindenmayer, D. B. \& Possingham, H. P. 2006: A new method for conservation planning for the persistence of multiple species. - Ecology Letters 9: 1049-1060.

Niemelä, J. 1997: Invertebrates and boreal forest management. - Conservation Biology 11: 601-610.

O’Dwyer, J. P. \& Green, J. L. 2010: Field theory for biogeography: a spatially explicit model for predicting patterns of biodiversity. - Ecology Letters 13: 87-95.

Olsson, J. \& Jonsson, B. G. 2010: Restoration fire and woodinhabiting fungi in a swedish Pinus sylvestris forest. Forest Ecology and Management 259: 1971-1980.

Pautasso, M. 2007: Scale dependence of the correlation between human population presence and vertebrate and plant species richness. - Ecology Letters 10: 16-24.

Philibert, C. 2003: Discounting the future. - Internet Encyclopaedia of Ecological Economics, International Society for Ecological Economics. [Available at http://isecoeco.org/pdf/philibert.pdf].

Polasky, S., Nelson, E., Camm, J., Csuti, B., Fackler, P., Lonsdorf, E., Montgomery, C., White, D., Arthur, J., Garber-Yonts, B., Haight, R., Kagan, J., Starfield, A. \& Tobalske, C. 2008: Where to put things? Spatial land management to sustain biodiversity and economic returns. - Biological Conservation 141: 1505-1524.

Pouzols, F. M., Toivonen, T., Di Minin, E., Kukkala, A. S., Kullberg, P., Kuusterä, J., Lehtomäki, J., Tenkanen, H., Verburg, P. H. \& Moilanen, A. 2014: Global protected area expansion is compromised by projected land-use and parochialism. - Nature 516: 383-386.

Pressey, R. L., Cabeza, M., Watts, M. E., Cowling, R. M. \& Wilson, K. A. 2007: Conservation planning in a changing world. - Trends in Ecology \& Evolution 22: 583-592.

Pressey, R. L., Watts, M. E. \& Barrett, T. W. 2004: Is maximizing protection the same as minimizing loss? Efficiency and retention as alternative measures of the effectiveness of proposed reserves. - Ecology Letters 7: 1035-1046.

Primack, R. B. 2006: Essentials of conservation biology, 4th ed. - Sinauer Associates, Sunderland, MA.

Pullin, A. S. 2002: Conservation biology. - Cambridge University Press, Cambridge, UK.

Pullin, A. S., Knight, T. M., Stone, D. A. \& Charman, K. 2004: Do conservation managers use scientific evidence to support their decision-making? - Biological Conservation 119: 245-252.

Pykälä, J. 2004: Immediate increase in plant species richness after clear-cutting of boreal herb-rich forests. - Applied Vegetation Science 7: 29-34.
Ranius, T., Korosuo, A., Roberge, J.-M., Juutinen, A., Mönkkönen, M. \& Schroeder, M. 2016: Cost-efficient strategies to preserve dead wood-dependent species in a managed forest landscape. - Biological Conservation 204: 197-204.

Rosenzweig, M. L. 1995: Species diversity in space and time. - Cambridge University Press, Cambridge.

Rybicki, J. \& Hanski, I. 2013: Species-area relationships and extinctions caused by habitat loss and fragmentation. Ecology Letters 16 (Suppl 1): 27-38.

Sang, A., Teder, T., Helm, A. \& Pärtel, M. 2010: Indirect evidence for an extinction debt of grassland butterflies half century after habitat loss. - Biological Conservation 143: 1405-1413.

Segerstöm, U., Bradshaw, R., Hörnberg, G. \& Bohlin, E. 2004: Disturbance history of a swamp forest refuge in northern Sweden. - Biological Conservation 68: 189-196.

Selonen, V. A. O., Ahlroth, P. \& Kotiaho, J. S. 2005: Anthropogenic disturbance and diversity of species: polypores and polypore associated beetles in forest, forest edge and clear-cut. - Scandinavian Journal of Forest Research 20 (Suppl. 6): 49-58.

Selonen, V. A. O. \& Kotiaho, J. S. 2013: Buffer strips can pre-empt extinction debt in boreal streamside habitats. - BMC Ecology 13: 24, doi:10.1186/1472-6785-13-24.

Stuart, S. N., Chanson, J. S., Cox, N. A., Young, B. E., Rodrigues, A. S. L., Fischman, D. L. \& Waller, R. W. 2004: Status and trends of amphibian declines and extinctions worldwide. - Science 306: 1783-1786.

Svancara, L. K., Brannon, R., Scott, J. M., Groves, C. R., Noss, R. F. \& Pressey, R. L. 2005: Policy-driven versus evidence-based conservation: a review of political targets and biological needs. - BioScience 55: 989-995.

Sverdrup-Thygeson, A. \& Ims, R. A. 2002: The effect of forest clearcutting in Norway on the community of saproxylic beetles on aspen. - Biological Conservation 106: 347-357.

Swift, T. L. \& Hannon, S. J. 2010: Critical thresholds associated with habitat loss: a review of the consepts, evidence, and applications. - Biological Reviews 85: 35-53.

Tear, T., Kareiva, P., Angermeier, P. L., Comer, P., Czech, B., Kautz, R., Landon, L., Mehlman, D., Murphy, K., Ruckelhaus, M., Scott, J. M. \& Wilhere, G. 2005: How much is enough? The recurrent problem of setting measurable objectives in conservation. - BioScience 55: 835-849.

Thomas, C. D., Cameron, A., Green, R. E., Bakkenes, M., Beaumont, L. J., Collingham, Y. C., Erasmus, B. F. N., de Siqueira, M. F., Grainger, A., Hannah, L., Hughes, L., Huntley, B., van Jaarsveld, A. S., Midgley, G. F., Miles, L., Ortega-Huerta, M. A., Townsend Peterson, A., Phillips, O. L. \& Williams, S. E. 2004: Extinction risk from climate change. - Nature 427: 145-148.

Tilman, D., May, R. M., Lehman, C. I. \& Nowak, M. A. 1994: Habitat destruction and the extinction debt. Nature 371: 65-66.

Toivanen, T. \& Kotiaho, J. S. 2007a: Burning of logged sites to protect beetles in managed boreal forests. - Conservation Biology 21: 1562-1572.

Toivanen, T. \& Kotiaho, J. S. 2007b: Mimicking natural 
disturbances of boreal forests: the effects of burning and creating dead wood on beetle diversity. - Biodiversity and Conservation 16: 3193-3211.

Toivanen, T. \& Kotiaho, J. S. 2010: The preferences of saproxylic beetle species for different dead wood types created in forest restoration treatments. - Canadian Journal of Forest Research 40: 445-464.

Toivanen, T., Liikanen, V. \& Kotiaho, J. S. 2009: Effects of forest restoration treatments on the abundance of bark beetles in Norway spruce forests of southern Finland. Forest Ecology and Management 257: 117-125.

Triantis, K. A., Borges, P. A. V., Ladle, R. J., Hortal, J., Cardoso, P., Gaspar, C., Dinis, F., Mendonca, E., Silveira, L. M. A., Gabriel, R., Melo, C., Santos, A. M. C., Amorinm, I. R., Ribeiro, S., Serrano, A. R. M., Quartau, J. A. \& Whittaker, R. J. 2010: Extinction debt on oceanic islands. - Ecography 33: 285-294.

Vanha-Majamaa, I., Lilja, S., Ryömä, R., Kotiaho, J. S., Laaka-Lindberg, S., Lindberg, H., Puttonen, P., Tammi- nen, P., Toivanen, T. \& Kuuluvainen, T. 2007: Rehabilitating boreal forest structure and species composition in Finland through logging, dead wood creation and fire: the EVO experiment. - Forest Ecology and Management 250: 77-88.

Widenfalk, O. \& Weslien, J. 2009: Plant species richness in managed boreal forests - effects of stand succession and thinning. - Forest Ecology and Management 257: 1386-1394.

Wilson, E. O. 2002: The future of life. - Knopff, New York, New York, USA.

Wilson, H. B., Joseph, L. N., Moore, A. L. \& Possingham, H. P. 2011: When should we save the most endangered species? - Ecology Letters 14: 886-890.

Visconti, P., Pressey, R. L., Giorgini, D., Maiorano, L., Bakkenes, M., Boitani, L., Alkemade, R., Falcucci, A., Chiozza, F. \& Rondinini, C. 2011: Future hotspots of terrestrial mammal loss. - Philosophical Transactions of the Royal Society B 366: 2642-2651. 